JOURNAL OF SECURITY AND SUSTAINABILITY ISSUES

ISSN 2029-7017 print/ISSN 2029-7025 online

2020 September Volume 10 Number 1

https://doi.org/10.9770/jssi.2020.10.1(19)

Scopus

\title{
CORPORATE RIGHTS AS DETERMINANTS OF THE ECONOMIC SECURITY MANAGEMENT OF THE COUNTRY
}

\author{
Oleksandr Yunin $^{1}$, Alina Goncharova ${ }^{2}$, Volodymyr Kovbasa ${ }^{3}$, Lina Doroshenko $^{4}$, Volodymyr Holubosh ${ }^{5}$ \\ ${ }^{1 *}, 3$ Dipropetrovsk State University of Internal Affairs, Ave. Gagarina, 26, 49005, Dnipro, Ukraine \\ ${ }^{2}$ Sumy State University, 2 Rimsky-Korsakova Street, Sumy, 40000, Ukraine \\ ${ }^{4}$ Vasyl'Stus Donetsk National University, st. 600-richchia, 21, Vinnytsia, 21021, Ukraine \\ ${ }^{5}$ Kyiv Institute of Intellectual Property and Law of the National University "Odessa Law Academy», \\ Kharkivske Shosse 210, Kyiv, 02121, Ukraine \\ E-mail: ${ }^{1 * k o a d u e p @ g m a i l . c o m ~(C o r r e s p o n d i n g ~ a u t h o r) ~}$
}

Received 19 December 2019; accepted 25 June 2020; published 30 September 2020

\begin{abstract}
It has been proven that foreign direct investment is an effective means of influencing the economic security of each country. Sectoral priorities of foreign investment can be divided into three groups: services sector, food industry and oil and gas sector. Capital investment in the services sector was determined by factors in the development of information and telecommunication technologies, internationalization of services and the implementation of liberalization policies by countries receiving direct foreign investments. The interest in attracting foreign investments in the above sector was shown by developed and developing countries. The oil and gas sector of Africa and North America has been an attractive investment object for international companies in West Asia. The increase in the number of M\&A agreement in the food industry has been observed in developed and developing countries and was conditioned by the interest of international companies in reducing production costs and expanding the source of revenue at the expense of growing market demand. The necessity to introduce a mechanism for management of corporate rights in the system of national security has been substantiated. The corporate rights and responsibilities of participants in corporate legal entities established in EU member states are the subject of harmonization of EU legislation in the area of company law only to the extent necessary to ensure an equivalent degree of protection of their interests within the Community, to create a favorable environment for the conclusion of cross-border agreements and the effective functioning of the domestic market.
\end{abstract}

Keywords: economic security, corporate rights, foreign direct investment, mergers and acquisitions (M\&As), civil proceedings

Reference to this paper should be made as follows: Yunin, O., Goncharova, A., Kovbasa, V., Doroshenko, L., Holubosh, V. 2020. Corporate rights as determinants of the economic security management of the country. Journal of Security and Sustainability Issues 10(1), 263-275. https://doi.org/10.9770/jssi.2020.10.1(19)

JEL Classifications: F35, F42

\section{Introduction}

The modern world economy formed under the influence of globalization processes is characterized by the growing role of foreign direct investment, which plays an important role as a means of achieving the goals of national development strategies, and host economies become part of their reproduction process. At the same time, in recent decades there have been observed a number of significant changes in the global structure of foreign direct investment, the growth rate of which is likely to increase in the short and medium term.

The position of developing countries and countries with economies in transition as objects and sources of global foreign direct investment is strengthening. Risks associated with political uncertainty and regional instability negatively affect the dynamics of international investment. As investment remains a leading factor in economic development, there arise a need to review international investment rules, which in practice means 
significant changes of legal, institutional and organizational-economic nature and the formation of a favorable investment environment.

In today world, where market relations clearly prevail and prove their effectiveness, corporations, being the main form of doing business and acting as a means of solving various socio-political and social issues, play a very important role. Within these legal entities there emerge special relations, the content of which, above all, are the corporate rights and responsibilities of their members. The latter are a key category for understanding the content and legal nature of corporate relations.

The purpose of the study is to determine the foundations of legal regulation of corporate rights and responsibilities of participants of corporate legal entities in the EU and make proposals for their harmonization in the area of company law.

\section{Literature Survey}

According to world experience, in economically developed countries, corporations are the basis of national economies. This is explained by the fact that they ensure the implementation of the main activities of the economy:

concentration of capital and its investment in competitive areas on world and national markets (Mentovich, A., Huq, A., \& Cerf, M. (2016));

reducing the confrontation between labor and capital (Drobyazko, S., et al. (2019a), Drobyazko, S., et al. (2019b));

formation of a corporate culture (Walt, S., \& Schwartzman, M. (2017));

overcoming the internal contradiction of man-owner and man-worker (Koev S., et al. (2020)).

Effective corporate management involves:

clear division of functions and responsibilities between the general meeting, the supervisory board and the executive body (Chen, T., Dong, H., \& Lin, C. (2020));

determining the scope of corporate rights of shareholders, the possibility to use effective means of their protection, equality of shareholders, as well as encouraging active cooperation between the company and stakeholders to create welfare, jobs and improve the financial condition of the company (Boatright, J. R. (2017)).

In a broad sense, corporate management is a system used to direct and control the operation of the company (Courteau, L., Di Pietra, R., Giudici, P., \& Melis, A. (2017)). Within the framework of corporate management, it is outlined how investors control the activities of managers, determine the responsibility that managers have to investors as a result of the company activities (Koev S., et al. (2020)).

The appropriate system of corporate management increases the confidence of investors that the company management wisely uses their investments for financial and economic activities of the company, which increases the value of investor share in capital (Osuji, O. K., \& Obibuaku, U. L. (2016)).

The appropriate corporate management should not be limited to the relationship between managers and investors, but should also provide for the importance of legitimate interests and active cooperation with stakeholders who have a valid interest in the company (consumers, employees, government, creditors, the public, etc.) (Jago, A. S., \& Laurin, K. (2017)). This is related to the fact that the company is not able to operate regardless of the environment in which it operates, and the end result of its activities is influenced by the contribution of all stakeholders.

From the standpoint of the institutional approach, corporate management is a system of formal and informal regulations that clarify property rights and ways to exercise these rights through various forms of personal and social control (Werhane, P. H. (2016)). 
Considering the nature of the corporation as a transparent system, the main objective of corporate management is to control and supervise the activities of management staff, which can be achieved through the use of external and internal control mechanisms (Siddiqui, J., \& Uddin, S. (2016)).

So, the core of corporate management is a system of relations between the owners of the company, its management staff and stakeholders for the effective operation of the company, the balance of influence of the interests of participants in corporate rights.

\section{Methods}

The methodological foundation of scientific research is a number of general scientific and special methods of cognition, namely: dialectical, formal-logical, logical-legal, comparative-legal, historical-legal, structuralfunctional methods, and the method of system analysis, as well as sociological, statistical and other methods.

Particularly, the historical-legal method provided a possibility to identify the basic patterns and features of the emergence and development of corporate rights and responsibilities; the comparative-legal method was used to identify common and different features in the corporate law of countries); statistical and graphical methods were used at the time of processing and generalization of statistical data and their presentation in the form of tables and figures; the method of abstraction was used to define and clarify certain concepts, in particular, the concept of corporate relations, corporate rights, corporate responsibilities, corporate legal entity. With the help of the system-functional method, the range of organizational and legal forms of corporations is determined, the characteristic of the rights and responsibilities of their participants is given. The formal-logical and logicallegal methods were used to identify the limitations of current legislation and justify areas for improvement.

The legal framework of the study are international legal acts, acts of the European Union.

\section{Results}

The existing world economy, which is being formed under the influence of globalization processes, is characterized by the growing role of foreign direct investment (FDI). FDI gives an opportunity to shape the social, economic, innovative, intellectual and infrastructural potential of the world economy. For countries that receive investments, they become the financial foundation for encouraging economic growth and increasing competitiveness in world markets, and attracting FDI is an integral condition of the investment strategy of a country.

The analysis of global FDI flows made it possible to identify the main countries-recipients of investments. The USA became the main recipient of foreign investments in 2018 having attracted $22 \%$ of global FDI, the second position in the list was taken by the UK with $15 \%$ of global FDI (Figure 1). China ranked third ( $8 \%$ ) having lost its leading position since 2014. The next two positions belonged to Hong Kong and the Netherlands with $6 \%$ and 3\%, respectively. It should be noted that in 2016 the countries of the Asian region received $25 \%$ of global FDI. Furthermore, of the ten main recipients of foreign direct investment, five have the status of developing countries. 


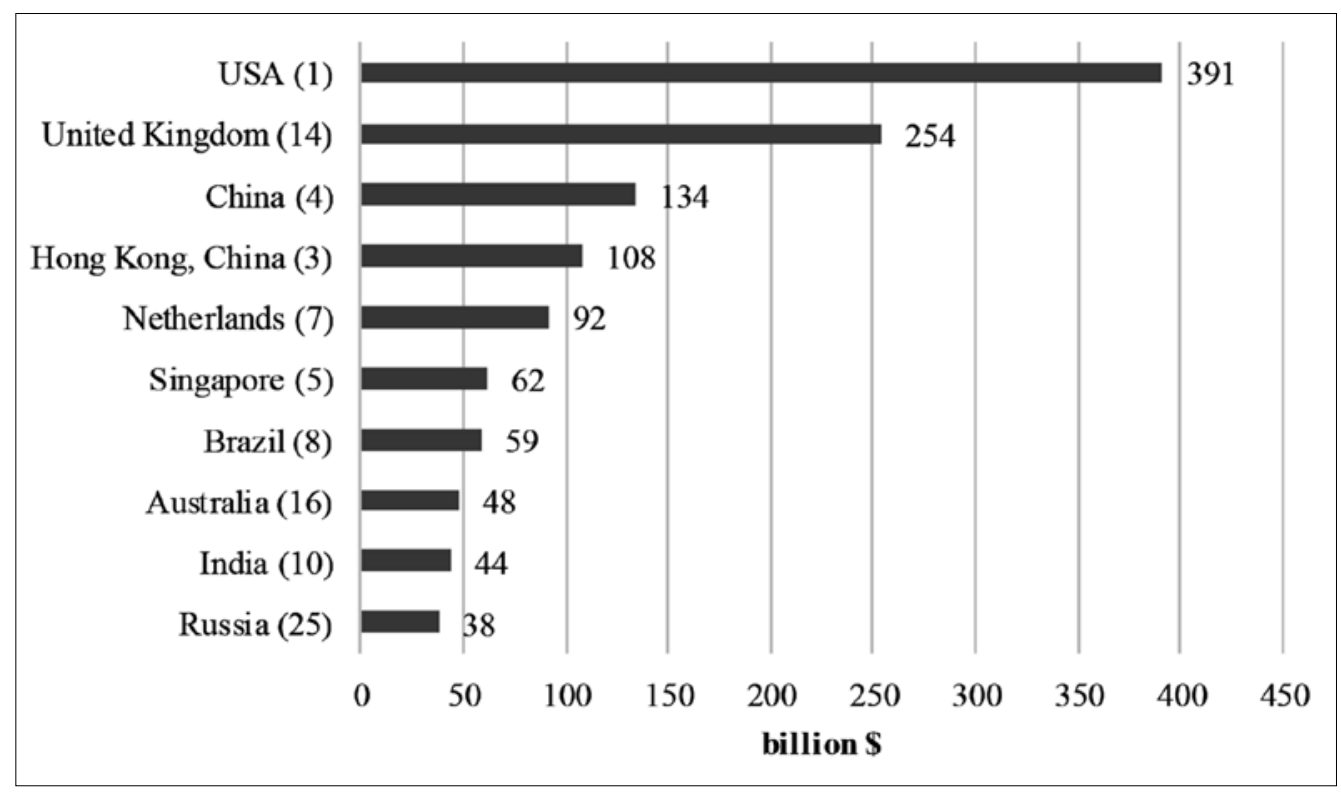

Figure 1. Top 10 foreign direct investment (FDI) recipients in 2018, billion USD

Source: World Investment Report 2019: Investment and the Digital Economy.

In 2018 , the USA were the main investor, which foreign investment accounted for $21 \%$ of global FDI investment, and China ranked second with $13 \%$. The next two positions were taken by the Netherlands and Japan with $12 \%$ and $10 \%$, respectively. It should be noted that in 2018 developing countries lost their position in the rating of major investment donors, attracting 26\% of global FDI export, compared to the record 35\% in 2014. Of the ten FDI donor countries in 2016, eight were developed countries, accounting for $72 \%$ of foreign investment (Figure 2).

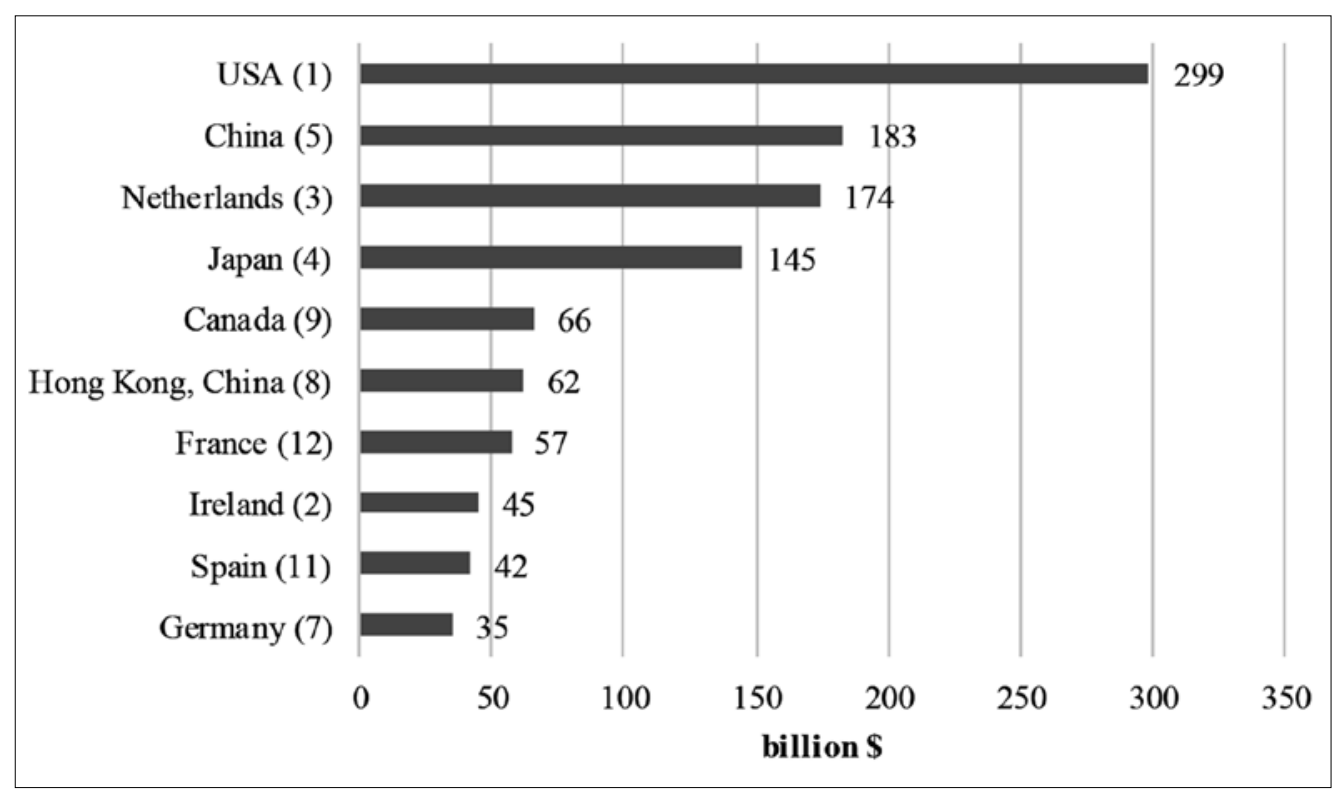

Figure 2. Top 10 foreign direct investment (FDI) donor countries in 2018, billion USD

Source: World Investment Report 2019: Investment and the Digital Economy.

The identification of sectoral priorities of direct investment for countries is an important issue, as in the current conditions of the world economy, such investments are the key to encouraging economic growth. In recent years, regional trade agreements have been playing an important role in intensifying the process of attracting 
investment into the economy of a country, the number of which is constantly increasing both between countries and between regional integration associations.

With respect to industries, the largest recipients of FDI were the sectors of manufacturing, finance, entrepreneurship, trade and telecommunications (Figure 3). There are five main industries in the manufacturing sector: chemical products, food and beverages, electronics, cars and oil products. They account for more than $70 \%$ of total foreign direct investment in the above sector. The primary sector is dominated by FDI in mining industries, including oil, gas and metal ores, while investment in the agricultural sector remains low. Low raw material prices have significantly affected FDI inflows into the primary sector over the past few years. The mining industry plays a significant role in the economies of developing countries, those of Africa, Latin America and West Asia, and they account for $20 \%$ to $30 \%$ of their FDI inflows (World Investment Report 2019: Investment and the Digital Economy).

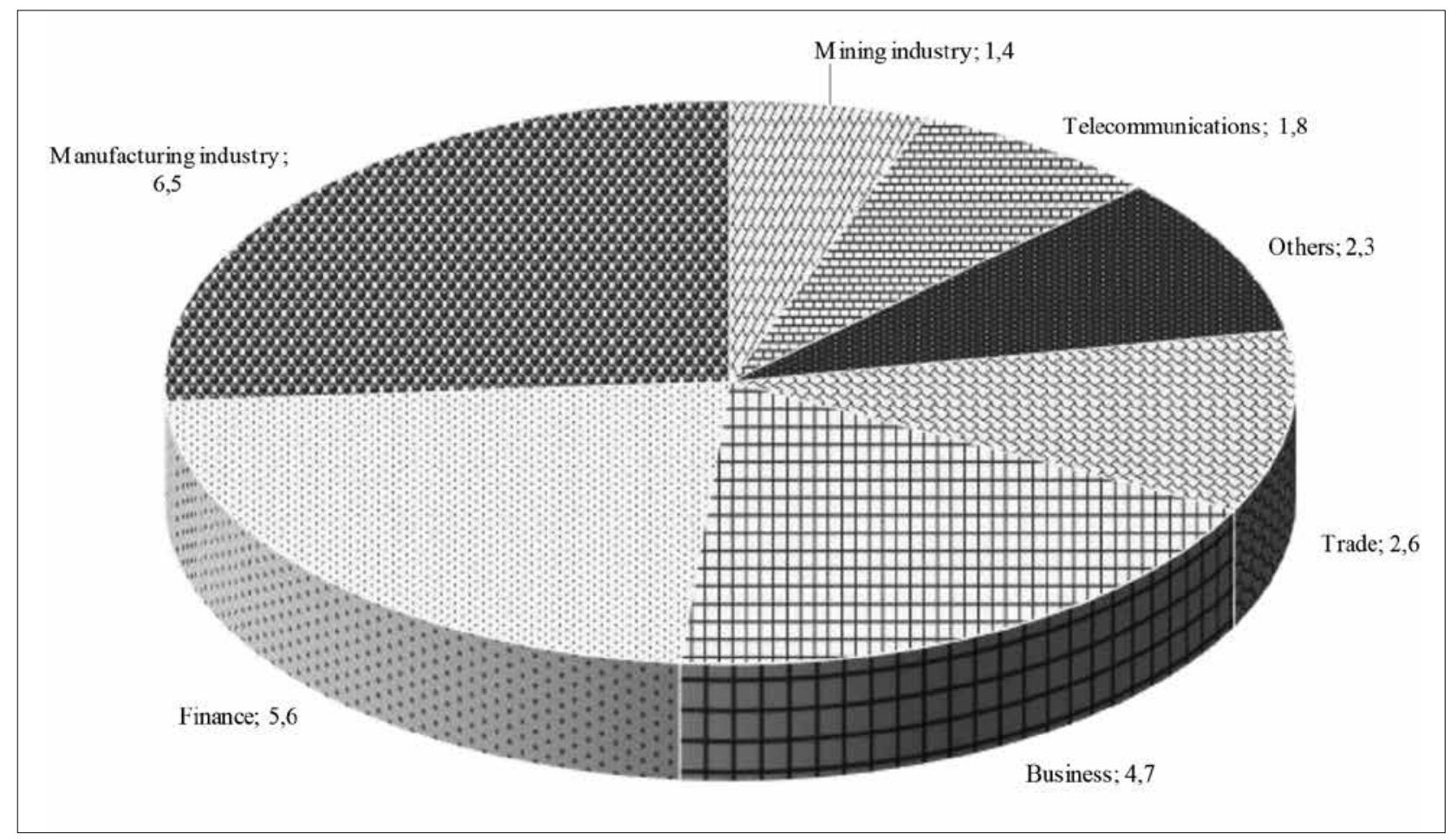

Figure 3. Volumes of foreign direct investment by economic sectors in 2018, billion USD.

Source: World Investment Report 2019: Investment and the Digital Economy.

As the services sector accounts for $70 \%$ of global value added, it can be argued that its share of global FDI flows will continue to increase in the future. In addition to long-term trends in the structure of the world economy, the increase in the share of FDI directed to the services sector is explained by a number of factors, including the progress in the development of information and communication technologies, which further contributes to transformation of services into a market product and growth of global supply chains, which contributes to the internationalization of services related to production. Another important factor is further liberalization of the sector in host countries, which makes it possible to attract large volumes of FDI, especially in areas traditionally closed for foreign investment, such as finance and telecommunications. Moreover, these changes are taking place in both developed and developing countries.

In the manufacturing sector, the total cost and distribution of cross-border M\&As have changed significantly over the last few years. In the sector of electronic equipment, food, beverages and tobacco, as well as machinery and equipment, an increase was recorded. In contrast, the amounts of M\&As in the sectors of pharmaceuticals, production of chemicals and chemical products decreased (Figure 4). 


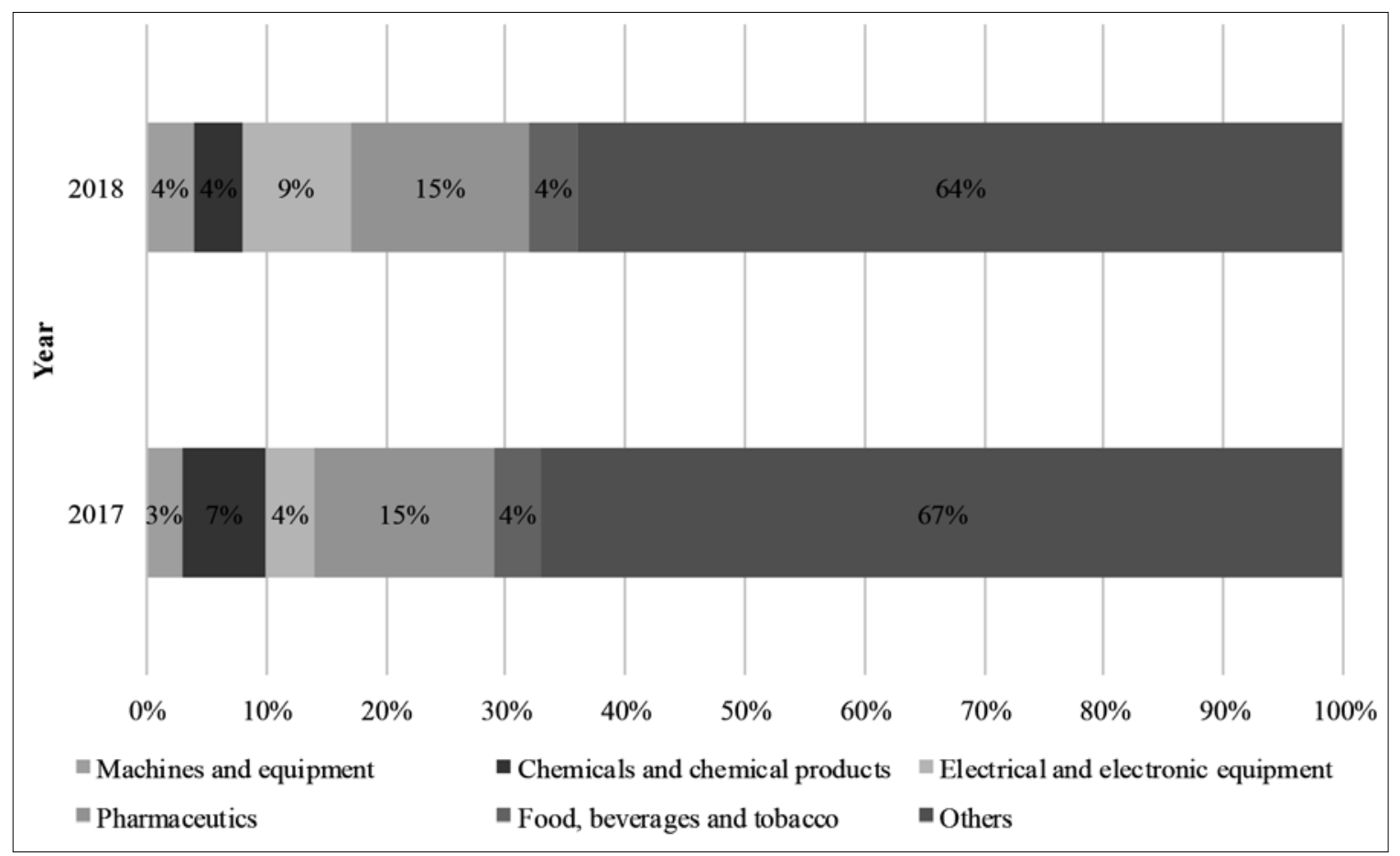

Figure 4. Distribution of foreign direct investment in cross-border M\&A by economic sectors in 2017 and 2018, \%

Source: World Investment Report 2019: Annex Tables

In the sectors of services, transportation and storage, entertainment and recreation, construction, there was an increase in cross-border M\&As in 2018, with growth rates of $34 \%, 71 \%$ and $116 \%$, respectively. It should be noted that in 2018 the volume of cross-border M\&As in the mining industries increased due to increased oil and gas production. FDI investments in new projects also increased significantly.

It should be noted that trends in the area of FDI into M\&As by economic sectors differ between the main groups of world countries. In developing countries, the amounts of M\&A decreased from USD 84 bln down to USD 69 bln (by 28\%), with a decrease in the countries of Asia (16\%) and Africa (55\%), and on the contrary, in Latin American and Caribbean countries there was an increase of $62 \%$. The amounts of M\&A has also almost halved in countries with transition economies. As for developed countries, in the area of cross-border M\&A there were observed opposite trends, the total value of which increased from USD 641 bln up to USD 794 bln (by 24\%) in 2016 (World Investment Report 2019: Investment and the Digital Economy).

In the last few years, there have been observed certain trends in the sectoral investment priorities of multinational companies. The role of foreign capital in the US oil and gas industry is growing, as small national market participants need to share the costs of developing and operating shale gas fields. Moreover, the development of shale gas fields has an impact outside the United States. American companies with the necessary experience in the development and operation of shale gas fields are also become the object of acquisition or partners in industrial cooperation with energy companies in other countries with rich shale fields. In particular, international companies (MNC) of Western Asia place their investments in North America (World Investment Report 2014: Investing in the SDGs: An Action Plan).

In addition to the oil and gas industry, the availability of cheap natural gas contributes to the attraction of FDI in new projects in the manufacturing industries, in particular in the production of chemical products and their derivatives. In addition, the repatriation of capital to the US MNCs in the manufacturing industry is expected (World Investment Report 2014: Investing in the SDGs: An Action Plan). 
Also, in recent years there have been changes in the pharmaceutical sector. International companies in this sector are seeking access to high-quality medicines with low production costs, so they are winding down their activities in non-core segments and using M\&A to generate new sources of income in developing countries, given the growing market demand. In addition, agreements on mergers and acquisitions provide access to successful research and development information of foreign companies. Moreover, the largest pharmaceutical MNC having huge reserves of retained earnings abroad facilitates the implementation of such agreements and indicates the likelihood of further activities in this regard (World Investment Report 2014: Investing in the SDGs: An Action Plan.).

An important trend in modern international trade is the creation of conditions for the participation of local firms in global value chains (GVC). Such conditions are a favorable investment and trade environment, which provides general conditions for business activities, including trade and investment policy, as well as tax and antitrust policy, labor market regulation, intellectual property, the possibility of privatization and ownership of agricultural land and a number of other policy areas.

As investment and trade are inextricably linked to GVC, it is important to ensure coherence between investment and trade policies. In this case, regional trade and investment agreements are particularly important, as regional liberalization efforts shape regional production systems and provide for distribution of value added (World Investment Report 2013: Global Value Chains: Investment and Trade for Development).

The EU is the largest FDI donor and recipient in the world. During 2005-2018, the volume of FDI inflows to the EU showed a fluctuating trend. It should be noted that in 2008 there was a sharp decline in FDI investment $(40 \%)$ as a result of the global financial and economic crisis, with negative trends observed during 2008-2010. In 2011, there was a sharp increase in investment inflows to the EU at the expense of the activation of M\&A agreements.

Some of such agreements was conditioned by the corporate restructuring of companies with the purpose of their focusing on key activities, reducing costs of non-core activities and more efficient use of capital. For example, in 2011 Carrefour SA (France) restructured Distribuidora Intemacional de Alimentacion (Spain) for USD 3.1 bln (World Investment Report 2012: Towards a New Generation of Investment Policies).

In 2016, FDI inflows to EU countries increased by 17\% up to USD 566.2 bln, changing in 2015 the dynamics of falling investment inflows in 2012-2014 (Figure 5). 


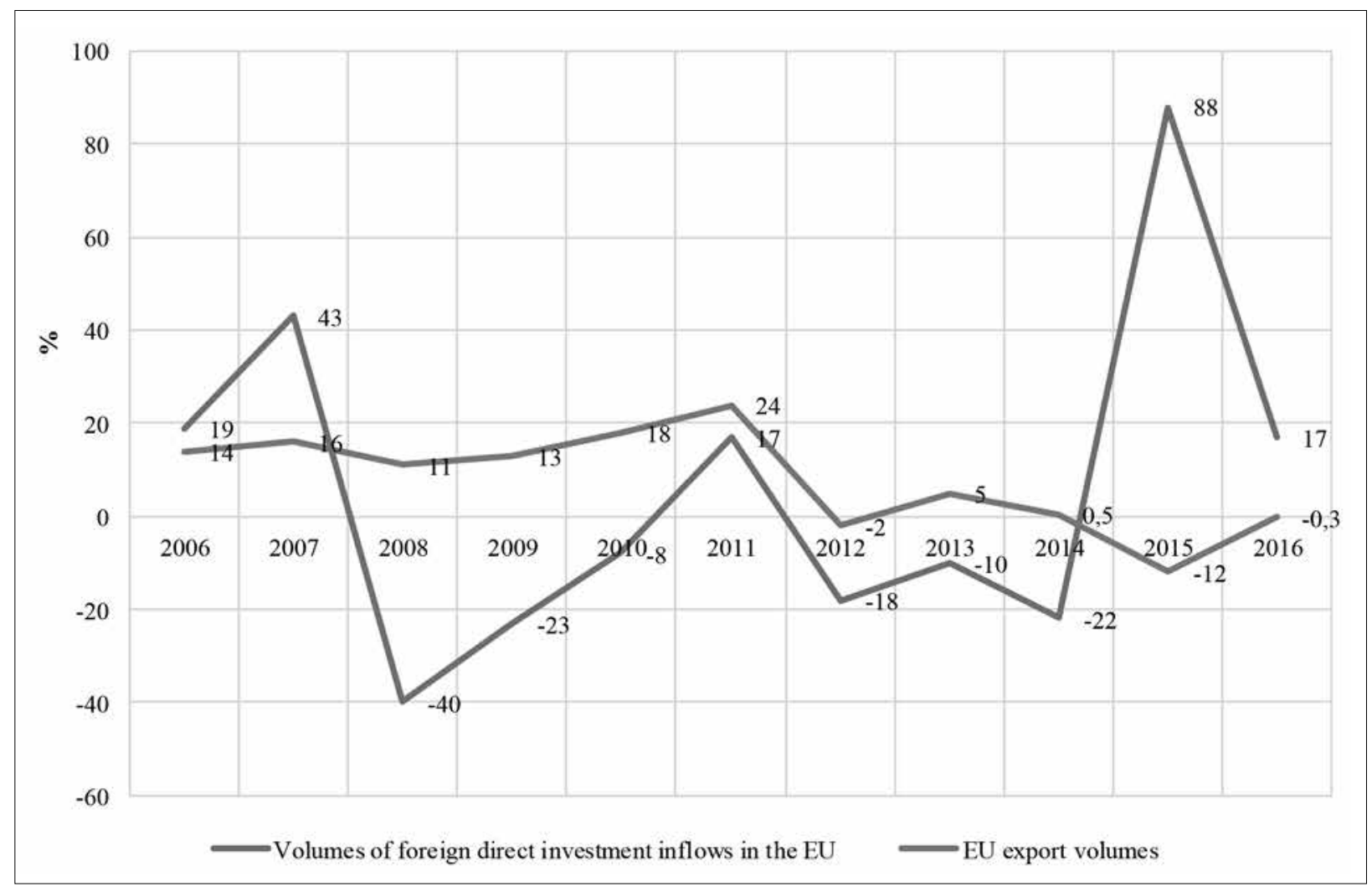

Figure 5. Growth rates of foreign direct investment and EU exports during 2006-2016.

Source: Exports of goods and services

Significant increase in investment inflows took place in such countries as the United Kingdom - almost 8 times, Croatia - 6.5 times, the Czech Republic - 14.5 times, Sweden - 3 times, Estonia - almost 7 times. In 2016, the decrease in investment inflows was observed in the following countries: Hungary, Germany, Denmark, Ireland, Cyprus, Latvia, Lithuania, Malta, Poland, Portugal, Slovakia, Slovenia, Finland, France.

According to the study, it can be argued that during 2005-2018 a number of significant changes is observed in the structure of global FDI:

Strengthening position of developing countries and countries with transition economies as recipients and donors of global FDI. During 2010-2014, they attracted more than half of global investment (in 2014, their share was 56\%). However, in 2018 their share decreased as the positions of developed countries in global investment strengthened;

The main component of the capital exported from developed countries is the equity capital, which in 2018 amounted to $74 \%$ of the total foreign investment, $49 \%$ of FDI exported by international companies of developing countries were investments in reinvested earnings;

In 2018, 91\% of cross-border M\&As were accounted for by MNC of developed countries, in contrast to 2014. About $70 \%$ of the acquisitions belonged to MNC from developing countries. At the same time, developing countries accounted for $62 \%$ of total cross-border investment in announced new projects, of which $45 \%$ were in Asian countries. Priority areas of foreign investment were services, oil and gas sector, food industry;

State-owned MNC intensified their investment activities. Although their number does not exceed $1 \%$ of the total number of corporations, in 2014 they accounted for more than $11 \%$ of global foreign direct investment flows; 
The importance of regional integration associations in the investment flows of Asia, Latin America and Africa is growing. The member states of BRICS, ASEAN and MERCOSUR acted as FDI recipients during 20052018. During this period, the main FDI donors were NAFTA and EU member states. In addition, China is strengthening its position as an investor (Tvaronavičienè 2018), which ranked second among major donor countries in 2018;

Risks associated with political uncertainty and regional instability negatively affect the dynamics of global investment.

Throughout their historical development, the countries that are now members of the European Union have improved the legal regulation of commercial activities of their citizens and other persons who have carried out such activities on their territory.

In XX century there was a revolution in all spheres of social life, including in the field of relations related to commercial activities. New offers of goods and services for the population began to appear on the market, more and more people were engaged in business. This necessitated the development of corporate relations and laying the foundations of corporate law.

Thus, along with the organizational and legal forms that are familiar to the national legal systems of the EU member states, some of them have certain modified forms of already known corporations - an entrepreneurial company in Germany, an investment company in Switzerland, a simplified joint stock company in France. Their appearance was a consequence and a corresponding reaction to the problem of "competition of legal orders" that arose in the EU (Chyzhmar, K., et al. (2019)).

Undoubtedly, "competition of legal orders" is an important step in the corporate law of European countries expanding corporate rights to members of companies, but such competition has led to the fact that many entrepreneurs registered their companies in one country by status in another country, which caused a number of economic issues, for example, in the field of taxation. It was necessary to solve this issue more quickly, so the reaction of national legal systems was the creation of new organizational and legal forms, which significantly simplified the requirements for companies and provided more loyal principles for creation of companies.

Thus, in almost all types of companies established in accordance with national laws, the requirements for authorized capital were significantly reduced making the amounts more accessible to ordinary people who intended to create their own companies. Another positive aspect is that legislators have paid considerable attention to the protection of corporate rights and interests of company members, such as in the Swiss investment company (Klochko, A.N., Kulish, A.N., Reznik, O.N. (2016)). You can consider all these reforms as a success of European lawmakers in the field of corporate law. They promoted the interest of individuals in doing business with minimal risk to their rights and protection of property.

When talking about the regulation of corporate rights and responsibilities of participants of corporate legal entities created in the EU member states, you should note the following. They are a subject of the harmonization of EU company law only to the extent necessary to ensure an equivalent degree of protection of the interests of companies within the Community in order to create a favorable environment for the conclusion of cross-border agreements and the effective operation of the domestic market. These are mainly individual rights of participants in certain organizational and legal forms, namely the right to information, including the right to receive documents related to the company activities, and the right to participate in the management of listed companies which shares are admitted to trading on a regulated market.

One of the leading goals of the Community, both in the field of economic activity and in the regulation of company law, was to create a legal basis that would effectively regulate the creation and operation of a new form of legal entity - the European legal entity. This was intended to subject such legal entities to a single law which would apply in the territory of all member states. 
The matter of granting legal standing to such an association remains at the discretion of national law, despite the fact that it has the characteristics of legal entities. In particular, the association may act independently in trade; to be a plaintiff and defendant in court. It should be noted that the majority of member states recognize such an association as a legal entity, with the exception of Italy and Germany. It should be noted that this organizational-legal form has a number of special features compared to other supranational legal entities of the EU and contains a number of features characteristic of general partnerships and some cooperative forms of organizations. Thus, as already mentioned, the purpose of the association is not to make a profit, but to promote or develop the economic activities of its members and improve or enhance the results of such activities. At the same time, it is determined that the activities of the association should be related to the economic activities of its members and be only additional to it. In terms of the responsibilities of the participants, the European association by economic interests resembles a general partnership.

In the same way, as in a European company, the issue of responsibility of the association members for transactions concluded before the moment of registration and subsequently not approved by the association has been resolved.

There are now around 24 million companies in the EU, $80 \%$ of which are private companies, $98-99 \%$ of private companies are SMEs (small and medium-sized companies). Companies are actively using modern digital technologies in their business, but they all have different and often limited opportunities to use new digital methods of communication with government agencies and their shareholders. Some states offer their companies simple and convenient continuous online procedures, and in some of them such procedures still require a physical presence in a certain place, paperwork, recourse to intermediaries (notaries, registration agents), etc.

The purpose of digitalization of EU corporate law is to equalize the possibilities of using online tools for companies from different EU countries to conduct their core operations.

The main task is to ensure the full online availability of these processes: company registration; submission and receipt of information about the company; reorganization; voluntary liquidation (dissolution) of the company; on-line communications between the company and shareholders, company bodies (internal communications).

Particular attention should be paid to the availability of online processes in cross-border transactions, procedures should be available regardless of the presence of a "foreign element" in the legal relationship, that is the location of the company and its participants in different countries should not harm online processes (at least for EU countries).

\section{Discussion}

The emergence of corporate rights is in some way associated with the acquisition of shares of joint stock companies, shares in the authorized (composed) capital of other companies, shares in the property of production cooperatives, the legal nature of which is obviously similar and which can be generally understood as corporate shares. At the same time, the practice identifies numerous shortcomings in the implementation of legislative provisions on corporate rights and corporate shares, which make possible, among other things, such a negative phenomenon of legal reality as legally motivated corporate captures (corporate raiding).

At the same time, the issues of accounting for rights to corporate shares, unregistered as securities, that is different from shares and their encumbrances, remain unresolved, the forms of termination of such corporate shares are not regulated, the moment of acquisition and termination of corporate rights at their sale is not determined, which raises the question of whether a person can acquire ownership of a corporate share and not simultaneously become a member of a corporate organization, there is no proper detail of the powers that constitute the corporate rights of members of general and limited partnerships, members of farm enterprises.

In an economic environment, the hierarchy of sources of indirect control in descending order of importance 
is as follows: power in all its manifestations and varieties; legal norms and their violations; disposal of assets, operations and income of the joint-stock company; business relations; information, or rather the asymmetric distribution of information; property of debt holders; family ties (e.g . Wati, L. N., Ramdany, Momon, (2020)).

When disclosing information, the company should not be limited to factual information, but also disclose reasonable forecasts regarding the future results of its business activities and financial condition. Most of the decisions made by participants in corporate relations on the basis of information provided by the company are financial. Therefore, during the inspection it is necessary to pay special attention to the reliability and timeliness of disclosure of information about the financial and economic activities of the company.

Increasing the level of control over corporate rights makes it possible to improve the system of corporate management. A quality system of corporate management is a condition for the effective operation of companies, gives them access to global capital markets, as well as in terms of business ethics consolidates the social commitments of joint stock companies, that is makes it possible to form corporate social responsibility.

Corporate social responsibility is determined by the profitability of the business and the liabilities of companies to their shareholders, employees and trade unions. In the European Union, corporate social responsibility is included in employment and social affairs policy, entrepreneurship policy, environmental policy, consumer protection policy, public procurement policy and external relations policy.

In the current business conditions, the introduction of corporate social responsibility is an element of effective improvement of the company, which will improve business reputation, economic and financial performance, strengthen staff motivation.

\section{Conclusions}

According to the results of the study, it can be concluded that international investment indicators show differences in the dynamics between regions of the world, mainly due to global economic instability and political uncertainty. First of all, this is due to the fact that in the conditions of unstable economic prospects, international corporations of developed countries continue to support a restrained policy of new investments or get rid of foreign assets instead of expanding their activities. At the same time, MNCs of developing countries and transition economies, on the contrary, are interested in expanding their foreign operations. And although the international production of MNCs has increased and at the end of 2018 cash reserves were estimated at USD $18.5 \mathrm{trn}$, up $48 \%$ from the pre-crisis period of 2005-2007, they continue to refrain from investing their record high cash holdings.

Since 2005, the amount of foreign direct investment has been gradually increasing on a global scale. In 20072009, there was a sharp decline in global FDI flows, which was due to the financial and economic crisis. During 2009-2018, there were constant fluctuations in foreign investment due to political uncertainty and economic instability, which affect the investment decisions of MNCs. Tendencies to increase investment were observed in developed countries and countries with transition economies except for developing countries. In 2016, among developed countries, the main FDI recipients were the United States, United Kingdom, the Netherlands and Australia, among developing countries - the countries of Asia (China, Hong Kong (China), South Korea, Singapore, Malaysia, Vietnam), and among the countries with transition economies - Russia and Kazakhstan. In 2018, the amount of foreign investment decreased in all groups of countries. The main FDI donors were the United States, China, the Netherlands and Japan.

As a result of the study, it is found that the end-to-end conflict of internal corporate interests, an effective system of motivational factors and strict responsibilities based on continuous monitoring of the company performance, are key preconditions for effective corporate control. Also, it is established that the introduction of the internal control system by an economic entity, in particular in terms of corporate rights, which are expressed in the form of shares, bonds and financial investments, will provide senior management with information about each share- 
holder having them, which will allow to timely detect abuse and protect the rights of shareholders.

In companies, internal control of corporate rights plays an important role in the effective corporate management of joint stock companies. However, a number of scientific aspects of the methodology of internal control of corporate rights of shareholders are insufficiently developed and require in-depth study and formation of new approaches to their improvement, which actualizes further research.

\section{References}

Boatright, J. R. (2017). Ethics and corporate governance: Justifying the role of shareholder. The Blackwell guide to business ethics, 38-60. Available at: https://onlinelibrary.wiley.com/doi/abs/10.1002/9781405164771.ch2

Chen, T., Dong, H., \& Lin, C. (2020). Institutional shareholders and corporate social responsibility. Journal of Financial Economics, 135(2), 483-504. Available at: https://www.sciencedirect.com/science/article/abs/pii/S0304405X19301643

Chyzhmar, K., Kolomiets, T., Dniprov, O., Sydorov, O., Rezvorovich, K. (2019). The peculiarities of the legal regime of information in the e-declarations of persons authorized to perform the functions of state or local self-government. Journal of Legal, Ethical and Regulatory Issues. 22(5). Available at: https://www.abacademies.org/articles/the-peculiarities-of-the-legal-regime-of-information-in-the-edeclarations-of-persons-authorized-to-perform-the-functions-of-state-8613.html

Courteau, L., Di Pietra, R., Giudici, P., \& Melis, A. (2017). The role and effect of controlling shareholders in corporate governance. Journal of Management \& Governance, 21(3), 561-572. Available at: https://link.springer.com/article/10.1007/s10997-016-9365-1

Drobyazko, S., Blahuta, R., Gurkovskyi, V., Marchenko, Y., Shevchenko, L. (2019). Peculiarities of the legal control of cryptocurrency circulation in Ukraine. Journal of Legal, Ethical and Regulatory Issues, 22(6). URL: https://www.abacademies.org/articles/peculiaritiesof-the-legal-control-of-cryptocurrency-circulation-in-ukraine-8813.html

Drobyazko, S., Okulich-Kazarin, V., Rogovyi, A., \& Marova, S. (2019). Factors of influence on the sustainable development in the strategy management of corporations. Academy of Strategic Management Journal. Available at: https:/www.abacademies.org/articles/ factors-of-influence-on-the-sustainable-development-in-the-strategy-management-of-corporations-8623.html

Exports of goods and services. https://data.worldbank.org/indicator/BX.GSR.GNFS.CD

Jago, A. S., \& Laurin, K. (2017). Corporate personhood: Lay perceptions and ethical consequences. Journal of Experimental Psychology: Applied, 23(1), 100. Available at: https://psycnet.apa.org/record/2016-62675-001

Klochko, A.N., Kulish, A.N., Reznik, O.N. (2016). The social basis of criminal law protection of banking in Ukraine. Russian journal of criminology, 10(4), 790-800. https://doi.org/110.17150/2500-4255.2016.10(4).790-800

Koev S., Blecharz P., Shafranova K., Karpenko S., Morozova Y. (2020). The Concept of Sustainable Development of Electronic Entrepreneurship in the International Business System. International Journal of Entrepreneurship, Volume 24, Special Issue. URL: https:// www.abacademies.org/articles/the-concept-of-sustainable-development-of-electronic-entrepreneurship-in-the-international-businesssystem-9326.html

Koev S., Pavliuk S., Derhaliuk M., Sokolova L., Portna O. (2020). Resource Strategy for Enterprise Management as a Tool to Ensure its Competitiveness. Academy of Strategic Management Journal, 19(4). URL: https://www.abacademies.org/articles/resource-strategyfor-enterprise-management-as-a-tool-to-ensure-its-competitiveness-9360.html

Mentovich, A., Huq, A., \& Cerf, M. (2016). The psychology of corporate rights: Perception of corporate versus individual rights to religious liberty, privacy, and free speech. Law and Human Behavior, 40(2), 195. Available at: https://psycnet.apa.org/record/2015-48257-001

Osuji, O. K., \& Obibuaku, U. L. (2016). Rights and corporate social responsibility: Competing or complementary approaches to poverty reduction and socioeconomic rights?. Journal of Business Ethics, 136(2), 329-347. Available at: https://link.springer.com/article/10.1007/s10551-014-2523-y

Siddiqui, J., \& Uddin, S. (2016). Human rights disasters, corporate accountability and the state. Accounting, Auditing \& Accountability Journal, 29(4), 679-704. Available at: https://www.ingentaconnect.com/content/mcb/059/2016/00000029/00000004/art00007

Tvaronavičienè, M (2019). Insights into global trends of capital flows' peculiarities: emerging leadership of China. Administratie si Management Public, (32), 6-17. https://doi.org/10.24818/amp/2019.32-01

Walt, S., \& Schwartzman, M. (2017). Morality, Ontology, and Corporate Rights. Law \& Ethics of Human Rights, 11(1), 1-29. Available at: https://www.degruyter.com/view/journals/lehr/11/1/article-p1.xml 
Wati, L. N., Ramdany, Momon. (2020). Does corporate governance affect financial reporting quality of politically connected firms? Entrepreneurship and Sustainability Issues, 7(3), 2126-2143. https://doi.org/10.9770/jesi.2020.7.3(45)

Werhane, P. H. (2016). Corporate moral agency and the responsibility to respect human rights in the UN Guiding Principles: do corporations have moral rights?. Business and Human Rights Journal, 1(1), 5-20. Available at: https://www.cambridge.org/core/journals/ business-and-human-rights-journal/article/corporate-moral-agency-and-the-responsibility-to-respect-human-rights-in-the-un-guidingprinciples-do-corporations-have-moral-rights/0DB3AE259A0229EABC14BF4F9DA3992A

World Investment Report 2012: Towards a New Generation of Investment Policies. Switzerland: United Nations, 2012. Available at: http://unctad.org/en/PublicationsLibrary/wir2012_embargoed_en.pdf

World Investment Report 2013: Global Value Chains: Investment and Trade for Development. Switzerland: United Nations, Available at: 2013. http://unctad.org/en/PublicationsL ibrary/wir2013_en.pdf

World Investment Report 2014: Investing in the SDGs: An Action Plan. Switzerland: United Nations, 2014. Available at: http://unctad. org/en/PublicationsLibrary/wir2014_en.pdf

World Investment Report 2019: Annex Tables. Geneva: United Nations. Available at: http://unctad.org/en/Pages/DIAE/World\%20Investment\%20Report/Annex-Tables.aspx

World Investment Report 2019: Investment and the Digital Economy. Geneva: United Nations, 2019. Available at: http://unctad.org/en/ PublicationsLibrary/wir2019_en.pdf

Short biographical note about the contributors at the end of the article:

Oleksandr YUNIN, Doctor of Legal Sciences, Professor, Dnipropetrovsk State University of Internal Affairs

ORCID ID: orcid.org/0000-0003-4846-2573

Alina GONCHAROVA, PhD in Law, Associate Professor, Academic and Research Institute of Law Sumy State University ORCID ID: orcid.org/0000-0002-9815-0394

Volodymyr KOVBASA, PhD in Law, Vice-Rector of Dnipropetrovsk State University of Internal Affairs ORCID ID: orcid.org/0000-0003-4468-4056

Lina DOROSHENKO, PhD, Associate Professor, Vasyl' Stus Donetsk National University ORCID ID: orcid.org/0000-0001-9748-6358

Volodymyr HOLUBOSH, PhD in Law, Associate Professor, Kyiv Institute of Intellectual Property and Law of the National University «Odessa Law Academy»

ORCID ID: orcid.org/0000-0001-9748-6358

Register for an ORCID ID:

https://orcid.org/register

This work is licensed under the Creative Commons Attribution International License (CC BY). http://creativecommons.org/licenses/by/4.0/ 